\title{
REVITALISASI WAKAF UNTUK KEMASLAHATAN UMAT
}

\author{
Ana Indah Lestari \\ Peneliti pada Wakaf Masjid Agung Jawa Tengah \\ e-mail: anaindahlestari@gmail.com
}

\begin{abstract}
Islam as a perfect teaching places the position of waqf as a very important instrument of society. The use of waqf as one of the resources used by the Muslim community has made progress now. This is evident from the increasing number of waqf assets in Indonesia. Aside from being a source of funding for social, educational and health activities, waqf can also be used as an alternative to empower the people $>_{S}$ economy as the main pillar of the welfare of the ummah, so that the benefits are sustainable. With the concept of waqf revitalization, it is expected to be able to support to improve the empowerment of waqf for the benefit of the ummah. Revitalization of waqf is not only able to give positive impact that can be felt directly but also indirectly able to form a professional waqf management capable of developing waqf so that waqf can become the strengthening of prosperity of the people.
\end{abstract}

Keywords: Waqf, Revitalization, Social Welfare

\section{Pendahuluan}

Islam sebagai agama paripurna dengan dua sumber pokoknya, yakni al-Quran dan as-Sunnah merupakan suatu 
agama yang lengkap, universal, dan berlaku sepanjang zaman dan tempat. Islam juga sarat dengan muatan nilai-nilai moral dan sosial sebagai pedoman hidup (the way of life) bagi umat manusia di dunia dan di akhirat.

Kesempurnaan Islam bisa dilihat ketika islam berbicara tentang hubungan antara makhluk dengan sang khalik (hubungan vertikal) dan hubungan antara sesama manusia (hubungan horizontal), sehingga tidak terjadi kesenjangan sosial antara yang satu dengan yang lainnya dalam komunitas kehidupan masyarakat diantaranya diwujudkan dengan amalan wakaf.

Mengenai harta wakaf, wakaf adalah suatu ibadah yang disyariatkan, wakaf telah berlaku sah bilamana wakif telah menyerahkan hartanya. Harta yang telah diwakafkan menyebabkan wakif tidak mempunyai hak kepemilikan lagi, sebab kepemilikannya telah berpindah kepada Allah SWT dan tidak juga menjadi milik penerima, tetapi si wakif tetap boleh mengambil manfaatnya.

Gambaran kegiatan wakaf pada masa dahulu dapat kita lihat jelas sejak masa awal penyiaran dan perkembangan Islam di Indonesia. Pada masa awal penyiaran dan perkembangan Islam di Indonesia wakaf hanya diperuntukkan untuk pembangunan sarana penunjang kegiatan dakwah berupa tempat ibadah. Pada saat itu, kegiatan wakaf yang ada dimasyarakat hanya berorientasi pada bentuk wakaf dan bangunan seperti untuk pembangunan masjid, musholla, langgar, sekolah, pondok pesantren, madrasah, yayasan, panti asuhan dan pekuburan. Bentuk kegiatan wakaf yang semacam ini berlangusng sangat lama dan relatif hampir sama diseluruh wilayah Indonesia. Keberadaan bangunanbangunan tersebut pada masa itu memang sangat dibutuhkan oleh masyarakat banyak karena pemerintah belum mampu menyediakan fasilitas-fasilitas tersebut.

Akan tetapi, seiring dengan perkembangan jaman, tanah dan bangunan wakaf tersebut dari tahun ke tahun semakin bertambah banyak jumlahnya namun tak terpelihara karena tidak 
adanya sumber finansial yang dapat diguakan untuk mengelola dan mengembangkan aset wakaf tersebut. Bahkan untuk sekedar biaya perawatan dan perbaikan saja hanya didapat dari kotak amal yang tidak seberapa jumlahnya dan harus mencarikan sumbangan dari para dermawan.

Perkembangan ekonomi sosial masyarakat yang begitu pesat saat ini menuntut masyarakat terhadap aset wakaf yang tidak hanya memberikan manfaat dalam hal peribadatan tetapi juga kesejahteraan masyarakat, tidak hanya yang bersifat tradisional-konsumtif tetapi juga yang bersifat modern-produktif. Untuk mewujudkan hal tersebut diperlukan suatu konsep yang disebut dengan konsep revitalisasi wakaf.

\section{Pembahasan}

\section{Konsep Wakaf}

\section{Pengertian wakaf}

Secara bahasa wakaf berasal dari kata al-waqf (wakaf), al-habs (menahan), dan at-tasbil (berderma untuk sabilillah). Kata wakaf adalah bentuk masdar dari ungkapan waqfu asysyai' yang berarti menahan sesuatu (Abdurrohman, 2013: 5). Sedangkan menurut islitalh, kata tersebut didefinisikan sebagai suatu tindakan penahanan dari penggunaan dan penyerahan aset dimana seseorang dapat memanfaatkan atau menggunakan hasilnya untuk tujuan amal, sepanjang barang tersebut masih ada (Muhammad Nafik dan Bashlul Hazami, 2016: 242).

Dari segi fiqh, para fuqaha berbeda pendapat dalam mendefinisikan wakaf, perbedaan itu tergantung pada mazhab yang mereka anut, seperti menurut ulama Hanafiyah, ketika berbicara tentang wakaf, ulama Hanafiyah membedakan antara definisi yang diutarakan oleh Imam Abu Hanifah sendiri dengan para pengikutnya. Al-Murginani menutip definisi dari Abu Hanifah yang menyatakan bahwa wakaf adalah: Menahan substansi harta pada kepemilikan wakif dan menyedekahkan manfaatnya." 
Mayoritas ulama Hanafiyah yang meriwayatkan definisi ini dari Abu Hanafiah ini belum tuntas dalam menjabarkan makna wakaf. Kamal Bin Himam mengatakan bahwa menurut definisi ini, seorang wakif masih bisa menjual harta itu jika dia menginginkan. Hak kepemilikan juga masih ada padanya, sebagaimana sebelum dia memberikan manfaat harta itu sebagai sedekah. Hal ini karena wakif hanya menyatakan keinginan untuk menyedekahkan manfaat harta, sehingga dia bisa memutuskan amalnya kapan saja, seperti halnya sebelum dia mewakafkannya. Ibn Abidin juga meriwayatkan dari Abu Hanifah yang mendefinisikan wakaf dengan: "Menahan substansi harta dengan memberikan legalitas hukum pada kepemilikan wakif dan menyedekahkan manfaat harta tersebut meskipun secara global."

Dalam mendefinisikan wakaf ini, Ibn Abidin menambahkan kata legalitas yang memberikan penegasan bahwa hukum (legalitas) yang ada dalam definisi diatas maksudnya adalah jika wakaf sudah menjadi pasti maka secara otomatis wakaf sudah beralih kepemilikannya dari wakif. Sedangkan menurut Abu Yusuf dan Muhammad, wakaf ditahan sebagai milik Allah SWT dan manfaatnya diberikan kepada mereka yang dikehendaki. Milik Allah berarti harta itu sudah tidak lagi menjadi milik wakif dan berpindah kepada orang lain, tetapi menjadi milik Allah. Dengan wakaf, unsur kepemilikan harta mutlak menjadi milik Allah dan manfaat harta itu untuk seluruh hamba-Nya dan untuk dikelola bagi kepentingan umat (Abdurrohman, 2013: 8-9). Manakala ulama Malikiyah mendefinisikan wakaf sebagai "Memberikan manfaat sesuatu, pada batas waktu keberadaannya, bersamaan tetapnya sesuatu yang diwakafkan pada pemiliknya, meskipun hanya perkiraan." Penyebutan kalimat 'memberikan manfaat' maksudnya mengecualikan pemberian barang, seperti hibah. Karena orang yang berhibah memberikan barang kepada orang yang dihibahi. Kalimat 'sesuatu' maksudnya selain manfaat uang atau yang diuangkan, karena sesuatu itu cakupannya lebih umum, hanya saja dikhususkan dengan definisi tetapnya kepemilikan. Kalimat 
'batas waktu keberadaannya' adalah kalimat penjelas untuk sesuatu yang dipinjamkan dan sesuatu yang dikelola. Hal itu karena orang yang meminjamkan berhak untuk menarik barang yang dipinjamkan. Kalimat 'tetapnya wakaf dalam kepemilikan si pemberi wakaf' adalah kalimat penjelas, maksudnya, maksudnya bahwa orang yang diberi wakaf ibarat seorang hamba yang melayani tuannya hingga meninggal. Artinya, penerima wakaf tidak punya hak milik atas harta wakaf yang dijaganya itu. Kalimat 'meskipun hanya perkiraan' maksudnya adalah kepemilikan atau pemberian (Abdurrohman, 2013: 10). Sedangkan menurut ulama Syafi'iyah, dalam kitab Tahrir al-Faz atTanbih, Imam Nawawi yang bermadzhab Syafi'i mendefinisikan wakaf sebagai: "Penahanan harta yang bisa dimanfaatkan dengan tetap menjaga keutuhan barangnya, terlepas dari campur tangan wakif atau lainnya, dan hasilnya disalurkan untuk kebaikan semata-mata dan taqarrub (mendekatkan diri) kepada Allah." Definisi ini mempertegas terlepasnya harta dari kepemilikan wakif, terlepas dari campur tangan wakif atau lainnya, dan hasilnya disalurkan demi kebaikan semata-mata untuk mendekatkan diri kepada Allah SWT. adapun ulama dari Madzhab Syafi'i menjelaskan sebagai berikut: 1) Menurut Ibn Hajar al-Haitami, wakaf adalah menahan harta yang dimanfaatkan dengan menjaga keutuhan harta tersebut, dengan memutus kepemilikan barang dari pemiliknya untuk hal-hal yang dibolehkan. 2) Menurut Al-Minawi, wakaf adalah menahan harta benda yang dimiliki dan menyalurkan manfaatnya dengan tetap menjaga pokok barang dan keabadiaanya yang berasal dari para dermawan atau pihak umum selain dari harta maksiat semata-mata karena ingin mendekatkan diri kepada Allah SWT. 3) Sedangan menurut Al-Qalyubi menerangkan bahwa wakaf adalah menahan harta yang bisa diambil manfaatnya dengan menjaga bentuk aslinya untuk disalurkan kepada jalan yang dibolehkan (Abdurrohman, 2013: 11-12). 
Wakaf menurut ulama Hanabilah, yang dikemukakan oleh Ibn Qudamah, salah seorang ulama Hanabilah adalah: "menahan yang asal dan memberikan hasilnya."

Definisi wakaf yang dikemukakan oleh ulama Hanabilah ini berasal dari hadist Nabi Saw kepada Umar bin Khatab ra., "Tahanlah asalnya dan alirkanlah hasilnya." Maksud dari kata "asal" adalah barang yang diwakafkan dan maksud dari kalimat "mengalirkan manfaat" adalah memberikan manfaat barang yang diwakafkan berupa keuntungan dan hasilnya, untuk kemaslahatan umat (Abdurrohman, 2013: 13).

Para ulama kontemporer mendefinisikan wakaf adalah bahwa "Wakaf adalah menahan harta baik secara abadi mauun sementara untuk dimanfaatkan langsung atau tidak langsung, dan diambil manfaat jasilnya secara berulang-ulang dijalan kebaikan, umum maupun khusus."

Definisi wakaf ini mengandung delapan hal: 1) Menahan harta agar tidak dikonsumsi atau digunakan secara pribadi misalnya wakaf untuk masjid, sekolah dan kendaraan yang memberi manfaat untuk orang banyak. 2) Definisi wakaf ini mencakup harta, baik yang tetap dan tidak bisa bergerak seperti tanah dan bangunan, maupun berupa benda bergerak, berupa uang seperti deposito dan pinjaman. 3) Mengandung pengertian melestarikan harta dan menjaga keutuhannya, sehingga memungkinkan untuk dimanfaatkan secara langsung atau diambil manfaat dan hasilnya secara berulang-ulang. 4) Wakaf memiliki definisi berulang-ulangnya manfaat dan kelanjutannya baik yang berlangsung lama, sebentar atau selamanya. 5) Definisi wakaf ini mencakup wakaf langsung, yang menghasilkan manfaat secara langsung dari harta atau benda yang diwakafkan, sebagaimana juga mencakup wakaf produktif yang memberi manfaat dari hasil produksinya, baik berupa barang maupun jasa serta menyalurkan semua laba bersihnya sesuai dengan tujuan wakaf. 6) Mencakup jalan kebaikan umum untuk kagamaan, sosial, dan lain sebagainya. 7) Mecakup pengertian wakaf menurut fikih dan 
perundang-undangan, bahwa wakaf tidak terjadi kecuali dengan keinginan satu orang yaitu wakif saja. 8) Mencakup pentingnya penjagaan dan kemungkinan bisa diambil manfaatnya secara langsung atau dari manfaat hasilnya. Ini juga menentukan tugas yang mendasar bagi kepengurusan wakaf, dan peranannya dalam menjaga kelestariannya dan menyalurkan manfaatnya bagi orangorang yang berhak menerima wakaf baik dari masyarakat umum maupun kelompok tertentu. Dengan demikian, definisi wakaf ini mencakup wakaf abadi seperti tanah dan bangunan, serta wakaf yang berupa harta bergerak dan hanya berumur sesuai dengan tingkat kekekalan bendanya. Definisi ini mengakomodir empat mazhab (Hanafi, Maliki, Syafi'i dan Hambali) (Abdurrohman, 2013: 14-16). Sedangkan wakaf menurut undang-undang No. 41 tahun 2004 tentang wakaf, ditetapkan bahwa wakaf adalah perbuatan hukum wakif untuk memisahkan atau menyerakan sebagian harta benda miliknya untuk dimanfaatkan selamanya atau jangka waktu tertentu sesuai dengan ketentuannya guna keperluan ibadah atau kesejahteraan umum menurut syari'ah.

Definisi wakaf ini mengandung dua hal yaitu, pihak yang mewakafkan langsung disebut wakif tanpa memperinci pihak yang mewakafkan apakah perorangan, kelompok perorangan atau badan hukum dan durasi wakaf, dalam PP No. 28 tahun 1977 dan KHI ditetapkan bahwa wakaf bersifat mu'abbad (abadi, selamanya, atau langgeng), benda yang diwakafkan tidak dapat ditarik kembali karena bukan lagi menjadi milik wakif, melainkan milik umum. Adapun dalam Undang-Undang Nomor 41 Tahun 2004 terdapat ketentuan secara eksplisit yang menyatakan bahwa benda wakaf dimanfaatkan selamanya atau untuk jangka waktu tertentu. Oleh karena itu, dalam Undang-Undang Nomor 41 Tahun 2004 terdapat pengakuan terhadap wakaf mu'aqqat (jangka waktu tertentu) (Abdurrohman, 2013: 18-19). 


\section{Landasan hukum wakaf}

Ada beberapa dalil yang membahas tentang disyariatkannya wakaf, baik dari Al-Quran, As-Sunnah, dan ijma'

\section{a. Dalil Al-Quran}

Dalam Al-Quran terdapat beberapa ayat yang menganjurkan untuk menunaikan wakaf beberapa diantaranya:

Allah berfirman dalam surah Al-Imran ayat 92 yang berarti: "Kamu sekali-kali tidak sampai kepada kebajikan (yang sempurna), sebelum kamu menafkahkan sehahagian harta yang kamu cintai. dan apa saja yang kamu nafkahkan Maka Sesungguhnya Allah mengetahuinya." (QS. Al-Imran: 92)

Kehujjahannya adalah: kebaikan akan tergapai dengan wakaf. Hal ini berdasarkan riwayat bahwa Abu Talhah ketika mendengar ayat tersebut, beliau bergegas untuk mewakafkan sebagian harta yang ia cintai, yaitu beiruha', sebuah kebun yang terkenal dengan kesuburannya. Rasulullah telah menasehatinya agar ia menjadikan perkebunannya itu sebagai wakaf. Maka Abu Talhah mengikuti nasehat Rasulullah tersebut. Abu Ubaid mengatakan bahwa walaupun kata infak dalam ayat diatas menunjukkan arti sunnah, namun umat islam selalu dianjurkan untuk merealisasikan dan untuk mencapai tujuan infak tersebut. Dengan demikian, ayat di atas menjadi dalil atas disyariatkannya wakaf.

\section{b. Dalil As-sunah}

Hadist riwayat Muslim dari Abu Hurairah, Rasulullah bersabda yang artinya: "Telah meriwayatkan kepada kami, Yahya bin Ayyub, Qutaibah dan Ibn Hujr, mereka berkata, 'telah meriwayatkan kepada kami Isma'il dari al-'Ala' dari ayahnya dari Abu Hurairah, bahwasanya Rasulullah Saw. bersabda, 'jika seorang meninggal, maka terputuslah seluruh amalnya, kecuali tiga perkara : sadaqah jariyah, ilmu yang bermanfaat dan anak salih yang mendoakannya." (HR. Muslim, 1929: 68) 
Kehujjahanya adalah: sadaqah jariyah diterangkan oleh para ulama dengan nama wakaf. Imam Nawawi berkata bahwa dalam hadist tersebut ada dalil atas benarnya hukum wakaf dan agungnya pahala bagi yang melakukannya (Ahmad Furqon, 2012: 38).

\section{Jenis wakaf menurut pengelolaannya}

Menurut jenis pengeloaannya, wakaf dapat dibagi menjadi dua kelompok, yaitu sebagai berikut:

a) Pengelolaan wakaf secara tradisional, Yaitu pengelolaan harta wakaf diperuntukkan hanya untuk pembangunan fisik saja dan biasanya bersifat konsumtif, seperti: wakaf tanah untuk pengkuburan umum, pembangunan masjid, pembangunan madrasah dan lain sebagainya.

b) Pengelolan wakaf secara modern, Yaitu pengelolaan wakaf secara produktif atau memindahkan harta dari upaya konsumtif menuju produktif dan investasi dalam bentuk modal produksi dan sekarang sedang menjadi sorotan karena potensinya bagi perkembangan ekonomi di Indonesia, seperti: wakaf uang, wakaf saham, wakaf bangunan untuk disewakan dan wakaf tanah produktif.

\section{Revitalisasi Wakaf}

\section{Pengertian revitalisasi}

Menurut Menteri Pekerjaan Umum Nomor 18/ prt/M/2010, Revitalisasi adalah upaya meningkatkan nilai ekononomi lahan melalui pembangunan kembali suatu bangunan untuk meningkatkan fungsi bangunan sebelumnya. Revitalisasi bertujuan untuk mengembalikan vitalitas ataupun daya hidup sebuah bangunan atau kawasan pada suatu tempat yang dianggap potensial untuk dikembangkan. Umumnya revitalisasi dapat dikaitkan dengan proses peremajaan bangunan, dimana intervensi yang dilakukan dapat mencakup aspek fisik dan non 
fisik (ekonomi, sosial, budaya dan lain-lain) (Permen PU No. 18 Tahun 2010).

Bila dikaitkan dengan paradigma wakaf, revitalisasi wakaf merupakan sebuah upaya daur-ulang (recycle) manajemen dan pola pengembangan wakaf untuk memberikan inovasi baru, meningkatkan fungsi yang ada atau bahkan menghidupkan kembali fungsi wakaf yang pernah ada untuk kemaslahatan umat serta memberikan kontribusi yang positif pada kehidupan sosialbudaya dan terutama kehidupan ekonomi. Sedangkan menurut kamus besar bahasa Indonesia, Revitalisasi adalah proses, cara, dan perbuatan menghidupkan kembali suatu hal yang sebelumnya terberdaya (www.Kbbi.web.id/revitalisasi/).

Dari keterangan diatas dapat disimpulkan bahwa revitalisasi wakaf adalah suatu upaya, proses dan cara untuk menghidupkan kembali fungsi-fungsi wakaf secara haqiqi agar menjadi suatu yang vital atau perlu sekali untuk keberlanjutan kehidupan. Maka dari itu, penting untuk memperhatikan asasasas yang mendasar dari wakaf itu sendiri yaitu:

a. Asas keabadian manfaat, suatu benda wakaf itu bisa dikategorikan memiliki nilai keabadian manfaat apabila ada empat hal yaitu (1) benda wakaf tersebut dapat dimanfaatkan oleh orang banyak; (2) benda wakaf mermberikan nilai yang lebih nyata kepada para wakif itu sendiri. Secara material pare wakif berhak memanfaatkan wakaf tersebut sebagaimana berlaku pada penerima manfaat wakaf; (3) manfaat immaterial benda wakaf melebihi manfaat materialnya. Atau bisa diaktakan nilai eksentrik benda wakaf melebihi nilai intristiknya; (4) dan yang paling penting dari benda wakaf itu sendiri adalah tidak menjadikan atau mengarahkan kepada bahaya (mudharat) bagi orang lain dan wakif sendiri.

b. Asas Pertanggung-jawaban, pertanggung-jawaban merupakan asas paradigma baru wakaf. Sebagai sebuah ajaran yang memiliki dimensi ilahiyyah dan insaniyyah, wakaf harus dapat dipertanggungjawabkan baik didunia dan diakhirat kelak. 
c. Asas Profesionalisme Manajemen, manajemen pengelolaan menempati pada posisi paling penting dalam perwakafan. Karena yang oaling menentuka adalah ketika benda wakaf itu memiliki nilai manfaat, meskipun tidak tergantung pada pola pengelolaan bagus dan buruk. Jika selama ini pengelolaan wakaf terkesan seadanya dengan menggunakan pola manajemen kepercayaan dan sentralisme kepemimpinan yang mengesampingkan aspek pengawasan, maka dalam pengelolaan wakaf secara modern harus menonjolkan sistem manajemen yang lebih profesional. Dan asas profesionalitas manajemen ini harusnya dijadikan semangat pengelolaan benda wakaf dalam rangka mengambil kemanfaatan yang lebih luas dan lebih nyata untuk kepentingan masyarakat banyak (kemaslahatan). Istilah untuk manajemen profesional adalah TQM (Total Quality Manajement) dengan kerangka teori yang mengerucut pada 4 hal yaitu:

1) Amanah (dapat dipercaya). Secara umum, pola manajemen dianggap profesional jika seluruh sistem yang digunakan dapat dieprcaya, baik input atau outputnya. Input dalam sebuah pengelolaan bisa dilihat dari Sumber Daya Manusia (SDM)nya yang dalam hal ini adalah nadzhir yang setidaknya memiliki standar pendidikan yang tinggi dan standar moralitas yang unggul sehingga seluruh proses yang dilakukan dapat menghasilkan produk yang baik dan tidak merugikan orang lain.

2) Shiddiq (jujur) adalah sifat mendasar, baik yang terkait dengan kepribadian SDMnya maupun bentuk program yang ditawarkan sehingga konsumen atau masyarakat tidak merasa dimanfaatkan secara sepihak.

3) Fathanah (cerdas), hal ini sangat diperlukan untuk menciptakan produk (program) yang bisa diterima oleh masyarakat dengan menawarkan berbagai harapan yang baik dan maju.

4) Tabligh (menyampaikan informasi secara transparan). Sebenarnya konsep tabligh ini lebih kepada kemauan dan 
kemampuan menyampaikan segala informasi yang baik dan benar. Dalam manajemen, penyebarluasan informasi yang baik dan jujur sangat terkait dengan pola pemasaran dan pelaporan keuangan.

Abdurrohman Kasdi dalam bukunya yang berjudul Fiqih Wakaf dari Wakaf Klasik hingga Wakaf Produktif mengutip pendapat Sherafat Ali Hasymi menyatakan bahwa peran kunci manajemen wakaf terletak pada eksistensi pengelola wakaf, terutama nadzir dan tim kerja yang solid untuk memaksimalkan peran wakaf (Abdurrohman, 2013: 169). Dengan demikian, sudah sepatutnya manajemen wakaf didorong semaksimal mungkin untuk mencapai kinerja terbaik dan memainkan peran sosial secara signifikan.

Lembaga kenadhiran memiliki peran sentral dalam pengelolaan harta wakaf secara umum. Oleh karena itu, eksistensi dan kualitas SDM nadhir harus betul-betul diperhatikan. Secara umum pengelolaan wakaf dapat terarah dan terbina secara optimal apabila nadhirnya amanah dan professional. Karena dua hal ini akan menentukan apakah lembaga tersebut pada akhirnya bisa dipercaya atau tidak (Abdurrohman, 2013: 172-173).

Setelah merevitalisasi manajemen pengelola wakaf dan upaya mengoptimalisasi nadhir, langkah selanjutnya adalah merevitalisasi harta wakaf. Merevitalisasi harta wakaf tentunya memerlukan biaya yang tidak sedikit agar harta wakaf tersebut menjadi produktif. Bahkan tak jarang kita jumpai misalnya pembangunan masjid yang mandeg selama bertahun-tahun dikarenakan kekurangan dana pembangunan. Tak sedikit juga masjid yang memiliki tanah yang luas namun tidak dimanfaatkan secara optimal. Disinilah pentingnya peran nadhir dalam mengelola harta wakaf, sebenarnya nadhir dapat memilih beberapa model pembiayaan dari model-model pembiayaan Islami yang ada, untuk proyek wakaf produktif dengan tujuan mengoptimalkan fungsi harta wakaf sebagai prasarana 
untuk meningkatkan kualitas hidup dan kehidupan sumber daya insani.

Mundzir Qahf sebagaimana yang diungkapkan oleh Karnaen A. Pawawataatmaja dikutip dalam Pengelolaan dan Perkembangan Wakaf Kementerian Agama Republik Indonesia, membedakan pembiayaan harta wakaf produktif secara tradisional dan model pembiayaan harta wakaf produktif secara institusional (Kemenag RI, 2013: 98).

Dalam model pembiayaan harta wakaf tradisional, buku fikih klasik mendiskusikan lima model pembiayaan rekontruksi harta wakaf yaitu (Kemenag RI, 2013: 99-100): Pinjaman, Hukr (kontrak sewa jangka panjang dengan pembayaran lump sum yang cukup besar di muka), Al-Ijaratain (sewa dengan dua pembayaran), menambah harta wakaf baru dan penukaran pengganti (substitusi) harta wakaf. Dari kelima model ini hanya penambahan harta wakaf baru yang menciptakan penambahan pada modal wakaf dan peningkatan kapasitas produksi. Sedang empat model yang lain banyak kepada membiayai operasional dan mengembalikan produktifitas (rekonstruksi) semua harta wakaf.

Pembiayaan wakaf dengan menciptakan wakaf baru untuk melengkapi harta wakaf yang lama. Contoh pertama dari pembiayaan dengan menciptakan harta wakaf baru untuk melengkapi harta wakaf yang lama adalah wakaf air minum yang dilakukan oleh Utsman bin Affan kepada Rasulullah SAW. Dimotivasi oleh Rasulullah SAW, Utsman mampu membeli sumber air Raumah yang semula hanya diberikan sebagian, tetapi kemudian oleh pemiliknya setuju menjual lagi sebagian yang lain. Contoh lainnya adalah perluasan masjid Nabawi di Madinah yang diperluas selama periode pemerintahan Khalifah Umar, Utsman, Bani Umayyah dan Bani Abbasiyah. Setiap perluasan memiliki penambahan harta wakaf yang lama. Contoh lain dari penambahan harta wakaf terlihat pada penyediaan fasilitas baru berupa air, listrik, dan system pendingin atau pemanas. 
Sejarah Islam telah menyaksikan jenis pembiayaan dengan menambah harta wakaf baru pada harta wakaf yang lama, seperti pada masjid, sekolah, rumah sakit, panti asuhan, universitas, kuburan, dan lain-lain. Pembiayaan seperti ini mudah dianggap sah karena dibangun dan ditanamkan pada harta yang sudah berstatus wakaf. Wakaf dalam bentuk buku atau mushaf alQuran sebagai tambahan dari yang sudah ada di perpustakaan dan di masjid juga sudah merupakan praktek umum di seluruh dunia Islam.

Adapun model pembiayaan baru untuk proyek wakaf produktif secara institusional terdapat empat model pembiayaan yang membolehkan pengelola wakaf (produktif) memegang hak eksklusif terhadap pengelolaan, seperti (Kemenag RI, 2013: 103-109): Murabahah, Istishna, Ijarah, dan Mudharabah. Sebagai tambahan ada juga yang disebut berbagi kepemilikan atau Syari'atul al-Milk, dimana ada beberapa kontraktor yang berbagi manajemen, atau menugaskan manajemen proyek pada pihak penyedia pembiayaan, disebut model berbagi hasil (output sharing) dan sewa berjangka panjang.

1. Model Pembiayaan Murabahah. Penerapan pembiayaan ini mengharuskan Nadzir mengambil fungsi sebagai pengusaha yang mengendalikan proses investasi yang membeli peralatan dan material yang diperlukan melalui surat kontrak Murabahah, sedangkan pembiayaannya datang dari satu bank Islami.

2. Model Istisna. Model ini memungkinkan pengelola harta wakaf untuk memesan pengembangan harta wakaf yang diperlukan kepada lembaga pembiayaan melalui suatu kontrak Istishna. Lembaga pembiayaan atau bank kemudian membuat kontrak dengan kontraktor untuk memenuhi pesanan pengelola harta wakaf atas nama lembaga pembiayaan itu. Model pembiayaan Istishna juga menimbulkan hutang begi pengelola harta wakaf dan dapat diselesaikan dari hasil pengembangan harta wakaf 
dan penyedia pembiayaan tidak mempunyai hak untuk turut campur dalam pengelolaan harta wakaf.

3. Mudharabah. Pada model ini pengelola harta wakaf (nadzir) berperan sebagai pengusaha (mudharib) dan menerima dana likuid dari lembaga pembiayaan untuk mendirikan bangunan di tanah wakaf atau sejenisnya. Manajemen akan tetap berada ditangan pengelola harta wakaf dan tingkat bagi hasil ditetapkan sedemikian rupa sehingga menutup biaya usaha untuk manajemen sebagaimana juga penggunaan tanahnya.

4. Model pembiayaan berbagi kepemilikan. Model ini dapat dipergunakan apabila du pihak secara individual dan bebas memiliki dua benda yang berkaitan satu sama lain, seperti misalnya masing-masing memiliki separoh dari sebidang tanah pertanian tanpa mempunyai perjanjian secara formal. Operasionalisasi formal dari berbagai kepemilikan adalah pengelola harta wakaf mengijinkan lembaga pembiayaan untuk mendirikan sebuah gedung. Masing-masing pihak memiliki secara bebas dan terpisah kekayaan dan mereka setuju untuk membagi hasil yang diperoleh diantara mereka.

5. Model bagi hasil (output). Dalam model pembiayaan bagi hasil, wakaf menyediakan tanah dan harta tetap lainnya yang dimiliki wakaf, sedang lembaga pembiayaan menyediakan biaya operasional dan manajemen. Lembaga pembiayaan dapat juga menyediakan sebagian atau seluruh mesin sepanjang tanah disediakan oleh pihak non-manajemen sesuai dengan persyaratan Muzara'ah. Model ini cocok untuk lembaga pembiayaan yang menghendaki mengambil tanggung jawab menajemen, sedang pengelola harta wakaf mengambil posisi sebagai mitra tidur. Ini menjadi salah satu dari model dimana manajemen secara eksklusif akan berada ditangan lembaga pembiayaan.

6. Model sewa berjangka panjang. Pada model ini manajemen berada di tangan lembaga pembiayaan yang menyewa harta wakaf untuk periode jangka waktu panjang. Penyedia dana 
mengambil tanggung jawab kontruksi dan manajemen sewa secara periodic kepada pengelola harta wakaf.

Dengan berbagai macam model pembiayaan yang ditawarkan di atas, nadzir dapat memilih satu atau beberapa diantaranya yang dikira cocok untuk melakukan kerjasama dengan pihak investor guna menambah nilai manfaat harta wakaf yang ada sehingga manfaatnya benar-benar dirasakan umat, bukan hanya dalam hal peribadahan tapi juga dampak sosial yang meliputi masalah ekonomi, kesehatan, dan pendidikan.

Sebagai contoh, masjid yang memiliki tanah wakaf yang strategis berada di tengah pusat perdagangan dan perkantoran dapat dipotimalkan manfaatnya dengan merevitalisasinya dengan cara menawarkan kepada investor untuk berinvestasi terhadap tanah tersebut, seperti pembangunan Rumah sakit Islam, Mini Market, dan sebagainya. Sehingga dengan demikian perolehan keuntungan ekonomi dari tanah wakaf ini bisa mencapai berkali-kali lipat dibandingkan tanah wakaf tersebut dibiarkan diam saja.

Keuntungan dari adanya revitalisasi, secara ekonomi dapat diuraikan sebagai berikut: a) Nadzir wakaf yang professional tidak perlu bersusah payah mencari dana dengan mengajukan berbagai proposal bantuan dan mengedarkan serta menempatkan kotak amal disekitar masjid; b) Pendapatan dan hasil pengelolaan wakaf ini sangat menguntungkan dengan jumlah yang sangat besar, dan biaya operasional masjid setiap bulan bisa tercukupi, alat-alat dan bangunan masjid, perbaikan sarana dan prasarana masjid dipenuhi secara baik; c) Kondisi keuangan memadai, sehingga nadzir wakaf atau pengurus dapat mengembangkan dakwah Islamiyah, seperti: beasiswa bagi anak miskin, memberikan santunan fakir miskin, beasiswa pendidikan Islam, penyediaan modal pengusaha kecil dan sebagainya; d) Tanah wakaf yang dikelola dengan professional dan diberdayakan akanmencicpctakan lapangan kerja baru, menyejahterakan guru- 
guru ngaji, membayar pegawai kebersihan masjid, pengelola masjid, dan sebagainya (Abu Hazam, 2009: 106).

\section{Dampak revitalisasi wakaf pada kesejahteraan umat}

Revitalisasi wakaf memberikan dampak secara langsung maupun tidak langsung. Dampak langsung yang dapat dirasakan adalah peremajaan, perawatan, pengembangan dan penambahan nilai harta wakaf tersebut sehingga tidak hanya memperpanjang umur (apabila wakaf tersebut berupa bangunan) tetapi juga menambah nilai manfaat wakaf tersebut.

Sedangkan dampak tidak langsung dari revitalisasi wakaf adalah terbentuknya manajemen nadzhir profesional yang mampu mengelola wakaf secara produktif. Pemanfaatan wakaf untuk kegiatan produktif akan menjadi sumber pendanaan alternatif bagi penguat ekonomi umat. Umat dapat menggunakan wakaf untuk sesuatu yang produktif untuk menghasilkan keuntungan. Sehingga kegiatan wakaf bermanfaat dalam memperbaiki ekonomi umat, karena ekonomi adalah pilar utama dalam kesejahteraan umat.

\section{Simpulan}

Dari pembahasan yang telah dijelaskan, maka dapat disimpulkan bahwa wakaf di Indonesia selama ini hanya mengalami peningkatan kuantitas tanpa dibarengi dengan adanya perbaikan kualitas pengelolaannya. Hal ini menyebabkan harta-harta wakaf tersebut kurang mendapat perhatian dan terbengkalai sehingga hanya memberikan kontribusi yang kurang optimal untuk kesejahteraan umat.

Konsep revitalisasi wakaf diperlukan sebagai upaya untuk memanfaatkan wakaf secara luas yaitu lebih dari sekedar untuk kegiatan keagamaan dan pendidikan, tetapi juga untuk memperkuat ekonomi umat dengan memanfaatkan berbagai alternatif program yang pendanaannya bersumber dari wakaf. 
Dengan adanya konsep revitalisasi wakaf ini, bukan hanya memberikan dampak secara langsung saja terhadap fisik wakaf tersebut, tetapi juga dengan manajemen pengelolaannya. Bentuk wakaf juga dapat dikembangkan untuk memberikan alternatif sumber wakaf sehingga memperkuat kemampuan wakaf untuk membiayai operasionalnya sendiri.

\section{Daftar Pustaka}

Abdurrahman Kasdi, Fiqih Wakaf (Dari Wakaf Klasik Hingga Wakaf Produktif), Idea Press, Yogyakarta, 2013.

Abu Hazam al-Hadi, Upaya Pemberdayaan Tanah Wakaf Produktif Bagi Kesejahteraan Ummat, Jurnal Islamica, Vol. 4, No. 1, September, 2009.

Ahmad Furqon, Wakaf Sebagai Solusi Permasalahan Dunia Pendidikan di Indonesia, Jurnal Hukum Islam (JHI), Vol. 10. No. 1, Juni, 2012.

Kementerian Agama Republik Indonesia, Direktorat Jenderal Bimbingan Masyarakat Islam, Direktorat Pemberdayaan Wakaf, Pengelolaan dan Perkembangan Wakaf, Jakarta, 2013.

Muhammad Nafik Ryandoko dan Bashlul Hazami, Peran dan Implementasi Wakaf dalam Peningkatan Kesejahteraan Masyarakat, Jurnal Inferensia, Vo. 10, No. 1, Juni, 2016.

Peraturan Menteri Pekerjaan Umum (Permen PU), No. 18 Tahun 2010 tentang Tata Cara Penetapan Kawasan Khusus.

www.kbbi.web.id/revitalisasi/, diakses 10 Oktober 2017 pukul 11.36 WIB. 